\title{
Career Paths in Institutional Business Elites: Finnish Family Firms from 1762-2010
}

JUHA KANSIKAS

This article analyzes the career paths of family business executives in institutional business elites in Finland using an empirical database based on a Bourdieusian prosopographical approach. The results indicate that career paths became more complex but shortened in length toward the beginning of the twenty-first century. The early career paths of family executives changed from positions as assistants and salesmen in the eighteenth and nineteenth centuries to governance, chief executive officer (CEO), and management positions in the twentieth and twenty-first centuries. Compared with the founder generation, next-generation family members benefited from more rapid institutional business elite career paths. The complexity of the career paths in the institutional business elite increased in subsequent generations. However, although there were few family executives with a third- or fourth-generation background in family businesses, founder-generation family executives existed in each cohort, apart from the pioneering generation.

This article analyzes the career paths of family business executives within an institutional business elite in Finland from 1762 to 2010. ${ }^{1}$ The research data begin in 1762 because the first counselorship was

() The Author 2015. Published by Cambridge University Press on behalf of the Business History Conference.

doi:10.1017/eso.2015.37

Published online September 16, 2015

JUHA KANSIKAS is Senior Lecturer of Entrepreneurship at the Jyväskylä University School of Business and Economics. His primary research interests are business elites, entrepreneurship and family businesses. Contact information: P.O. Box 35 40014 JYU Finland. E-mail: juha.kansikas@jyu.fi.

1. The author acknowledges the contribution of the Finnish Economic History Association and the Finnish Literature Society and the authors of the biographies (130 academic researchers in the Finnish Economic History Association network). The author thanks project leader and editor Professor Ilkka Nummela (University of Jyväskylä) and managing editor Kirsi Keravuori (Biographical Center, Finnish Literature Society) for their mentoring; Tuomas Möttönen (University of Jyväskylä), Samppa Penttinen (University of Jyväskylä), Teemu Tuomisalo 
awarded in that year, which marks the emergence of an institutional business elite in Finland. The extended timeframe enables us to understand the operation of family firms, which typically exhibit multigenerational and long-term orientations toward business within an institutional business elite. Because family firms are multigenerational, their lifecycles span tens to hundreds of years, which makes them a particularly appropriate research focus for career path studies. Along with their multigenerational characteristics, Finnish firms have typically implemented intensive cooperation because of the lack of available resources. Cost-intensive resources were a particular challenge for firms, and cooperative capitalism was thus evident. ${ }^{2}$

This article addresses the need for additional studies that integrate the study of business and history into a single multidisciplinary research setting. ${ }^{3,4}$ The present study examined family executives who received the honorary title of "counselor," which was bestowed by the ruling government of Finland for distinguished service to the economy and society. ${ }^{5}$ Counselorships were awarded under the three ruling governments of Sweden (1762-1808), czarist Russia (1809-1917), and independent Finland (1917 to date). The title was awarded selectively and was limited to individuals who exhibited exceptional achievements, social influence, and success compared with other businesspersons.

Counselorships were awarded based on societal services. Individual achievements, but also membership in certain families and, in the case of Finland, service in a particular company, influenced the likelihood of receiving a counselor title. Because established family firms were important in a small economy, such as that of Finland, these firms' executives tended to receive nominations for counselorships based merely on the company's preeminent position. As a result, in the present study, the concept of a business elite involves an institutional elite, and the article focuses on the role of counselors, who were the executives of institutions recognized as leading business organizations in the Finnish economy. Because individual executives

(University of Jyväskylä), Risto Valjus (Biographical Center, Finnish Literature Society) and Niklas Alén (Biographical Center, Finnish Literature Society) for their support and assistance; project supervisory board members Prof. Susanna Fellman and Prof. Jari Ojala; and project researcher Tiina Hemminki.

2. Ojala and Karonen, "Business: Rooted in Social Capital over the Centuries," 99.

3. Colli, "The History of Family Business 1850-2000," 26.

4. Colli, "Contextualizing Performance of Family Firms: The Perspective of Business History," 14.

5. The present study focused on counselors with the following Finnish honorary titles: kauppaneuvos (counselor of sales and trade), vuorineuvos (counselor of mining), talousneuvos (counselor of commerce), maanviljelyneuvos (counselor of agriculture) and teollisuusneuvos (counselor of industry). 
might refuse to accept the title of "counselor," the results of this study are limited to a particular set of individuals in Finland's institutional business elite and cannot be generalized to the entire population of family firms within the country's institutional business elite.

Finland was chosen as the research context because the honorary title system has survived from 1762 into modern times and provides records for family business members in the institutional business elite for that time period. The career paths of individuals in the institutional business elite have been documented in biographies, making it possible to create a prosopographical database and to adopt a comparative approach. This lengthy time span of more than 200 years has led to challenges for this study's research setting. Career paths have differed over time, as reflected in the evolution of Finnish economics. Family firms dominated the era of merchant capitalismprivately owned firms were family controlled. Finland's economic activity increased in the late 1790s, when cities such as Old Karleby, Åbo, Jakobstad, Vasa, Björneborg, and Uleåborg had rights for foreign trade. Exporting among Finnish cities increased in the late eighteenth century. ${ }^{6}$ The era of merchant capitalism was typically based on diversification by business families, in which entrepreneurial careers were common. ${ }^{7}$ Merchant capitalism is an example of an evolutionary ecosystem in which business families were needed and in which they had business opportunities. As the number of family firms and the economic circumstances in which they operated vary across the decades, the database of family firm executives has been created based on the documentation available to identify family businesses and their family members.

Because family firms provide continuity, research that focuses on family firms increases our understanding of the structure of executive career paths in family firms, and contemporary career research typically studies individuals who share the same title. ${ }^{8}$ In the present study, the title of "counselor," held by an executive in a family business, was a critical factor distinguishing the careers of individuals in the institutional business elite from the careers of other business populations. Because the careers of members of family firms in the institutional business elite differed because of differences in their lifecycles, family member career paths in family businesses ranged from management to executive roles. ${ }^{9}$

6. Hekscher, "Sveriges ekonomiska historia från Gustav Vasa. Den moderna Sveriges Grundläggning,” 714.

7. Müller, "The Merchant Houses of Stockholm, c. 1640-1800. A Comparative Study of Early-Modern Entrepreneurial Behaviour."

8. Krause and Semadeni, "Last Dance or Second Chance?"

9. Moya, "A Family-owned Publishing Multinational." 
In theory, career path construction is a process that is influenced by other family members and other stakeholders, such as employers and colleagues, throughout the individual's career, ${ }^{10}$ which makes the study of family firms worthwhile for career path research. Networks have changed, as have career paths and the environments in which family firms operate. In nineteenth-century Finland, family firms faced increasing competition through global trade and through societal institutionalization. The increase in the number of private companies, together with banks' abilities to lend money, caused competition in pricing and in creating new relationships between firms. ${ }^{11}$ Business families in eighteenth- and nineteenth-century Finland typically played multiple roles in society. In addition to engaging in foreign trade, they participated in local politics, trading, and social events; they not only had changing career paths but also had changing societal statuses throughout their lives. ${ }^{12}$

Because career paths reflect an individual's complex career evolution, contemporary researchers have investigated the origins of career paths, timing in the stages of career paths, and the mechanisms underlying the career process. ${ }^{13}$ The career theories that have been used to compare career paths in recent decades can be characterized as future career and traditional career theories. ${ }^{14}$ The trends exhibited by career paths have changed as the linear and traditional careers characteristic of growing economies have been transformed in modern times into more complex nontraditional careers that include part-time work, self-employment, occupational changes, ${ }^{15}$ and the boundary-less careers created by the current need for unstructured career arrangements. ${ }^{16}$ These changes have produced portfolio careers that exhibit an increase in the number of positions and the frequency of work periods. ${ }^{17}$ Contextual changes, such as organizational changes, have also influenced careers in institutional business elites because of internationalization and diminished social cohesion. ${ }^{18}$ However, an individual's career stage, gender, and work experience also

10. Muja and Appelbaum, "Cognitive and Affective Processes," 696.

11. Kallioinen, "Verkostoitu tieto: informaatio ja ulkomaiset markkinat Dahlströmin kauppahuoneen liiketoiminnasas 1800-luvulla,” 167.

12. Keskinen, "Oma ja yhteinen etu. Kauppiaiden keskinäinen kilpailu ja yhteistyö Porin paikallisyhteisössä 1765-1845,” 337.

13. Lee et al., "Entangled Strands,” 1547.

14. van Vianen, et al., "Adaptable Careers."

15. Sullivan and Baruch, "Advances in Career Theory," 1563; Patzelt and Shepherd, "Negative Emotions."

16. Arthur and Rousseau, The Boundaryless Career, 6; Ibarra and Barbulescu, "Identity as Narrative," 150.

17. Henderson and Robertson, "Who Wants to be an Entrepreneur?," 279.

18. Heemskerk and Fennema, "Network Dynamics,” 825. 
influence career complexity and contribute to the stability of certain contemporary career patterns. ${ }^{19}$

Although career path stability, as opposed to career path construction, can be operationalized in terms of the number and duration of positions, the number of employers, and the frequency of unemployment periods, ${ }^{20}$ it is not the focus of the current research. With respect to the positions and work experience involved in career paths, the analysis was influenced by the research focus and the nature of the data. ${ }^{21}$ The current study focused on identifying the types of career paths taken by executives in family firms within an institutional business elite. Researchers have noted the need for longitudinal studies on the careers of members of institutional business elites that analyse career path mobility. ${ }^{22}$ Thus, this study investigated career development and the types of managerial and entrepreneurial career paths exhibited by executives in family firms of the Finnish institutional business elite from 1762 to 2010.

This article is organized into the following sections. The first section reviews the concept of an institutional business elite and the careers and career paths of members of an institutional business elite. The second section presents the prosopographical approach, the research setting, and the database construction. The third section presents the study results. The final section discusses the implications of the study results and the limitations of the present research.

\section{Institutional Business Elites and the Concept of Class}

Class is a distinct feature in the history of institutional business elites that distinguishes families from one another. Members of institutional business elites typically belong to a higher-status class based on family origin. The class origin of institutional business elites is based not only on the wealth provided by the resources that family businesses accumulate, but also on their cultural and political power in local society. Because the social status of family businesses influenced counselors' career development, being awarded the title of counselor was not simply a personal achievement; this title mainly enhanced the individual's societal impact and only partly influenced his or her family-based career path.

During the eighteenth and nineteenth centuries, Finland was a class-based society; membership in a higher-status class was

19. Biemann, Fasang, and Grunow, "Do Economic Globalization,” 1658.

20. Fadjukoff, Kokko, and Pulkkinen, "Changing Economic Conditions,” 296.

21. Jensen and Choudhuri, "Stability and Change," 16.

22. Friedman and Tedlow, "Statistical Portraits," 106. 
legitimized by education, wealth, and language. Over the course of the twentieth century, this class-oriented society was radically transformed through new legislation that provided free public education, public welfare systems, and progressive taxation to decrease the income gaps between families. Currently, elites in Finland are not as homogenous as they were in earlier decades. In addition, elites are increasingly influenced by social mobility and changes due to the globalization of business. ${ }^{23}$ However, it must be noted that merchant families in Finland have not been united group of businesspeople. Instead, they have consisted of businesses of different sizes and with different life cycles, from startups to well-established family dynasties. ${ }^{24}$ Together with these evolutionary economics, openness in recruiting processes, interactions within elite groups, and interactions between elite groups and other classes have also transformed Finnish elites. ${ }^{25}$

Social classes are distinguished from one another by economic circumstances and social status. ${ }^{26}$ An elite group can be defined as a class whose members are viewed as superior to those in other classes and who possess a greater amount and higher quality of economic resources. Membership in an institutional business elite is one form of elitism; elitism also occurs in politics, media, science, culture, and all types of organizations that involve power mechanisms. ${ }^{27}$ Social capital, in the form of weak and strong ties in the historical research setting of counselors, influences the birth of social classes. ${ }^{28}$ Whereas elite members favor other members belonging to same elite group, social capital, as an unequal asset among individuals, explains the homogeneity of elite construction. However, it must be noted that social capital in historical research is not just a source of positive outcomes; social relationships can also cause failures and other types of negative outcomes in business operations. ${ }^{29}$ Favoritism, as reflected through social relationships, constructs business elites, creating the characteristics of a class-based society in which elites select their members. Members of elite classes favor other group members through a cyclical process in which power accumulates

23. Ruostetsaari, "Social Upheaval and Transformation of Elite Structures: The Case of Finland."

24. Ojala, "Kerran porvareita," 211.

25. Ruostetsaari, "Nordic Elites in Comparative Perspective."

26. Flemmen, "Putting Bourdieu to Work for Class Analysis."

27. Ruostetsaari and Borg, "Sukupolvien valta-asemien muutos eliiteissä ja eduskunnassa."

28. Keskinen and Teräs, "Sosiaalinen pääoma ja luottamus - miten tehdä näkymätön voimavara näkyväksi,” 12-13.

29. Teague and Donaghey, "The Life and Death of Irish Social Partnerships: Lessons for Social Pacts,” 14-15. 
in hands of a few business networks. ${ }^{30}$ In line with the results of the Maclean et al. study in France and the Ellersgaard, Larsen, and Munk study in Denmark, ${ }^{31}$ Flemmen's ${ }^{32}$ study in Norway found that education does not provide the route through which new members join elites, although it protects the current elite's high social status. Rather than focusing on education, the institutional business elite adopts an authority, management, and practice orientation, which reveals the existence of corporate connections illustrated by certain individuals holding multiple positions on the boards of leading businesses in the field.

From the perspective of businesses and family businesses, a class society depends not only on the distribution of economic power but also on the amount of available financial capital. Both financial status and cultural capital influence the likelihood of membership in an elite social class. ${ }^{33}$

\section{Career Paths of Members of the Institutional Business Elite in Family Firms}

How have the career paths of business elites in family firms been studied in the extant literature? In family business organizations, careers are constructed in an environment of longevity, family control, and succession. The organizational environment favors longevity because it is risk averse and continuity oriented ${ }^{34}$ as a result of the control exhibited by family firms, which is based on management and ownership by a single family. ${ }^{35}$ Consequently, the family governance influencing career development in family firms produces a situation in which the next generation of the family succeeds the earlier generation. ${ }^{36}$ Studying longevity is a culturally oriented research topic, in which contextual and historical processes influence and alter culture. There are not only organizational and individual reasons for longevity; there are also explanations that are regional in nature. Thus, family firms need not only capable individuals and organizational design, but also regional knowledge to survive and to change business strategies over time. ${ }^{37}$ The current research on

30. Maclean, Harvey, and Kling, "Pathways to Power."

31. Ellersgaard, et al., "A Very Economic Elite."

32. Flemmen, "The Structure of the Upper Class."

33. Iellatchitch, Mayrhofer, and Meyer, "Career Fields."

34. Ginalski, "Can Families Resist”; San Román, Fernández Pérez and Gil López, "As Old as History."

35. Nordqvist, "Understanding Strategy Processes,” 12-14.

36. Chung and Luo, "Leadership Succession,” 352-353.

37. Napolitano, Marino and Ojala, "In Search of an Integrated Framework of Business Longevity,” 8. 
longevity lacks studies that combine both negative and positive firm trends and increase understanding on lifecycles of the same firms throughout economic periods of time. ${ }^{38}$

Elite careers differ from other careers in terms of the merits and achievements acknowledged by society in the form of counselorship nominations. "Counselor" is an honorary Finnish title that is awarded based on individual achievement. Because the title is not inherited, it reflects the extent to which the career paths of members of the institutional business elite involve individual achievement, as recognized by the ruling government and society as a whole. The current empirical study included 444 male (97.4\%) and 12 female (2.6\%) family executives, providing an overall sample of 456 counselors. Because career paths were gender specific (i.e., different career paths were associated with a particular gender), ${ }^{39}$ the sample employed in this study was particularly relevant for examining career paths. The methodology used a prosopographical database based on written biographies of the individuals in the sample, which was appropriate for investigating career paths in an institutional business elite because career paths have become more complex and less predictable in recent decades. ${ }^{40}$

Career studies are employed for multiple purposes in the current literature. Career path diversity, which is measured in terms of the number of occupational positions, is based on both individual and organizational characteristics. Changes in career paths can be explained based on social skills and individual behavioral traits, such as openness to new experiences and extroversion. ${ }^{41}$ Career mobility, which is measured by the frequency of job changes and the tendency to move from one position to another, ${ }^{42}$ predicts higher salary levels for early-career managers compared with mid- and late-career managers. ${ }^{43}$ European countries differ in terms of the extent to which social mobility is present, and the size of the elite group and the nature of educational institutions, families, associations, and organizations influence the extent to which social mobility occurs. ${ }^{44}$ The concept of career roles, which provides an explanation for careers

38. Riviezzo, et al., "Who Wants to Live Forever: Exploring 30 Years of Research on Business Longevity," 13.

39. Liebig and Sansonetti, "Career Paths," 400; Zhao, et al., "The Mediating Role,” 1270; Krueger Jr., et al., "Competing Models of Entrepreneurial Intentions,” 428; Smith, "Reflections on Using Life History," 499; Parasuraman, et al., "Work and Family Variables," 294.

40. Chudzikowski, "Career Transitions," 304.

41. Carless and Arnup, "A Longitudinal Study,” 88.

42. Veiga, "Mobility Influences," 79-80.

43. Lam, et al., "The Relationship."

44. Harvey and Maclean, "Capital Theory,” 116-117. 
and how they are constructed, is useful for studies that classify careers based on the characteristics of the typical tasks associated with those careers. In contrast to the job concept, the career role concept emphasises the content of careers. ${ }^{45}$ In the current study, career roles were not examined because the use of job titles made it possible to adopt a prosopographical approach to counselors and their career paths. The literature defines a career path as a series of career positions in an individual executive's career. A career path might include continuous service in the same family business and other tasks external to the business. Because careers were discontinuous, they differed in terms of quantity and quality. However, career paths were identified by applying the same template to the biographies to create a prosopographical database. The career path concept was specific to the present study because the careers that were analyzed belonged to members of an institutional business elite; society had recognized these elite members' achievements through the conferral of honorary titles.

The careers of members of an institutional business elite are recognized as "elite" because these executives hold powerful positions in contemporary society. Their power can be observed by examining the governance, political, and business positions that managers who are members of the institutional business elite held during their careers. ${ }^{46}$ Cohesion within an institutional business elite is maintained by recruiting other elite members into senior executive positions. ${ }^{47}$ In political careers, factors such as growth potential, skills, behavior, and political power influence career achievements. ${ }^{48}$ In addition, individuals who are members of an institutional business elite are more likely to participate in the governance of nonprofit, nongovernmental, and political associations; furthermore, the careers of members of an institutional business elite are involved in activity in other sectors of society in addition to in business. ${ }^{49}$ Networking among organizations creates multiple governance positions, which produces corporate connections between businesses; for example, the same individuals may serve on the boards of two or more firms, which is typical in the careers of members of an institutional business elite. $^{50}$

In Europe, elite networks are country specific; in countries in which power mechanisms are concentrated (e.g., France), there are

45. Hoekstra, “A Career Roles Model,” 170.

46. Useem and McCormack, "The Dominant Segment."

47. Hartmann, "Class-specific Habitus," 254.

48. Liu, et al., "Are You Willing,” 1452.

49. Useem, "The Social Organization," 567.

50. Mizruchi, "What Do Interlocks Do?,” 271. 
close relationships between businesses and the public sector. ${ }^{51}$ However, in some European countries (e.g., the Netherlands), social cohesion within the institutional business elite has declined because of global competition. ${ }^{52}$ In Finland, the power elite is integrated into society, and there is active interaction between politics and business. This overlap between the political and business spheres characterizes the evolution of the Finnish economy because the state has influenced businesses not only through legislation and taxation but also through direct political action. ${ }^{53}$ The government influences businesses by standardizing the products and services in terms of usability and safety. ${ }^{54}$ Additionally, public sector funding has an influence on some business operations-for example, in the construction industry.

Becoming part of the elite in the Finnish society has been linked not only to family relations, such as inheritance and marriages, but also to firm ownership and close relationships with local politicians. Simultaneously, the business elite had political power, and some cohorts, including those in the eighteenth century, had significant local political power and power in the cities in which they traded. ${ }^{55}$ Thus, because of the close relationships with the business elite, the number of businessmen of Russian origin is low in the case of Finnish counselors; the only exceptions appeared during the first two decades of the twentieth century, before Finland obtained its independence and the czar's power was diminished. ${ }^{56}$

An elite career occurs within closed networks with respect to recruiting for top positions, which reveals the upper-class status of the families of individual members of the elite. ${ }^{57}$ Similar to recruiting, communication within the elite community occurs within a closed network. ${ }^{58}$ This closed world is observed in the career construction of members of the institutional business elite; managers use explanatory narratives and storytelling to create socially desirable positions. ${ }^{59}$

From 1830 through the 1870s, family networks were a recruitment source for Finnish industrial executives, including founders

51. Yoo and Lee, "In Search of Social Capital," 542; Kadushin, "Friendship Among the French," 218; Maclean, et al., "Managerialism and the Post-war," 548.

52. Heemskerk and Fennema, "Network Dynamics," 826.

53. Ojala and Karonen, "Business: Rooted in Social Capital over the Centuries," 123.

54. Stokes and Banken, "Constructing an 'Industry': The Case of Industrial Gases, 1886-2006,” 13.

55. Keskinen, "Oma ja yhteinen etu. Kauppiaiden keskinäinen kilpailu ja yhteistyö Porin paikallisyhteisössä 1765-1845,” 181.

56. Paloheimo, "Business Life in Pursuit of Economic and Political Advantages in Early-Nineteenth-Century Finland,” 166, 211.

57. Ruostetsaari, "The Anatomy of the Finnish Power Elite,” 332-333.

58. Higley et al., "Elite Integration,” 49.

59. Maclean, et al., "Sensemaking, Storytelling," 33-34. 
and entrepreneurs, who focused on company loyalty. The increasing professionalization of Finnish executives and increases in firm size produced career paths that were based primarily on professional and formal networks. ${ }^{60}$ In modern Finland, industrial managers entered into working life later, after holding more positions than their historical counterparts. However, there was no variation in the length of their career paths from the onset of their careers to the point at which they obtained executive positions. ${ }^{61}$

For institutional business elites, career onsets are rooted in societal changes, such as the revolution of power mechanisms ${ }^{62}$ and global competition. ${ }^{63}$ Depending on the society, potential senior executives tend to be educated in elite schools. ${ }^{64}$ However, this was not the case in Finland, which does not have a history of elite schools. Together with societal forces, family background-social status and belonging to a particular family-creates membership in an elite, ${ }^{65}$ which endures despite social and political changes. ${ }^{66}$ Membership in an elite family produces continuity and stability in business relationships, ${ }^{67}$ which makes executives in family firms relevant for research on the career paths of institutional business elites because family firms provide a means for establishing continuity and accumulating societal power.

A family's ethnic background might also be associated with power in a society. The desire of new elite groups to construct a career within an established institutional business elite is based on the extent to which they are economically and socially integrated into society. ${ }^{68}$ The current study thus included a few cases of Russian businessmen in the nineteenth and early twentieth centuries. This study addressed the need for interdisciplinary research on contemporary careers that integrates new conceptual approaches and methodologies ${ }^{69}$ and the need for research on career success by examining the career paths of members of an institutional business elite. ${ }^{70}$ Some family executives, especially those within founder generations, were entrepreneurs.

60. Fellman, "Prosopographic Studies," 18.

61. Fellman, Uppkomsten av en Ddirektörsprofession, 160-162.

62. Kryshtanovskaya and White, "The Rise"; Kryshtanovskaya and White,

"From Soviet Nomenklatura."

63. Jones, "Re-theorising the Core."

64. Saveth, "Education of an Elite."

65. Mastekaasa, "Social Origins," 233.

66. Andrle, “The Buoyant Class,” 829-380; Clark and Soulsby, "The Re-formation,” 300.

67. Goodman, "Ethics and Enterprise," 437.

68. Zhou and Kim, "Formation, Consolidation, and Diversification," 245; Boyd, "Transformation of the Black Institutional Business Elite," 613-4.

69. Chudzikowski and Mayrhofer, "In Search of the Blue Flower?," 31.

70. Feldman and Ng, "Careers," 371. 
To address the research gaps described earlier, a prosopographical approach was adopted to provide a longitudinal perspective on family businesses and to extend the scope of current research on careers and career paths. The following section presents the prosopographical approach adopted in this study and describes the construction of the counselor database.

\section{Database Construction and the Prosopographical Approach}

The present study performed a prosopographical analysis of the family firm members of an institutional business elite. The empirical database employed in this study was provided by biographies written by 130 authors selected by the Finnish Economic History Association and the Finnish Literature Society; 64 percent of the authors held a doctoral or licentiate degree, and 36 percent had a master's degree. A third of the authors held positions as academic docents or professors at Finnish universities. All the biographies followed a uniform template and were based on data that spanned two and a half centuries. The framework provided by the template was designed by the researchers who directed the project and the research team that conducted the project and performed the data collection.

In the current study, the criteria of family control in a business were used to identify family businesses. ${ }^{71}$ To identify family businesses to be included in the study database, two researchers first reviewed the entire set of available biographies (1,598 biographies) and identified well-known family businesses. The researchers then used the biographies and secondary sources, such as media, the Internet, and business histories, to identify family firms in which voting control was in the hands of a single family or in which family members owned more than 50 percent of the shares of the same firm. In this study, a family firm executive was defined as an individual member of the family controlling the family business. Family firm executives who were members of the institutional business elite were defined as individuals who received the honorary title of "counselor" in Finland. Family firm executives were identified based on the information available in the biographies, as well as on secondary sources. Based on these criteria, 456 biographies from the larger set of biographies were the biographies of family executives.

Because the goal of prosopography is to generalize based on coded data, ${ }^{72}$ the database was constructed by coding all the variables that

71. Poza, “Family Business,” 8-9.

72. Uotila, “Käsityöläinen kyläyhteisönsä jäsenenä”, 37-39. 
could be identified in the counselor biographies. Three researchers coded the data in SPSS (IBM SPSS Statistics, Statistical Package for Social Sciences) format to make a statistical analysis possible. One of these researchers reviewed all the coded data to identify errors and typos. The time spent coding the biographies was one and one-half years; coding was performed at the University of Jyväskylä in Finland. Owing to the extended historical span of more than 200 years, information in the biographies that was vague or ambiguous was not coded. Similarly, a firm was excluded when it was not possible to determine whether it was a family or non-family business. The database construction followed prosopographical principles, specifically a Bourdieusian prosopographical approach, which is described below. The study results from the focus on the quantitative database and its contribution from the perspective of career paths. To increase our qualitative understanding of counselors, representative cases from each cohort are selected for more detailed descriptions. The aim of these cases is to enhance our understanding of what types of categories exist in the biographical data and how diverse the family executives in family firms throughout the cohorts are. The cases present the following categories: founder-generation, second-generation, third-generation, and fourth-generation counselors. The categories contain both industrialand marketing-oriented counselors who made their careers, as is typical in family firms, in the private sector and through close corporate connections with other private firms. They also provide information on both counselors with entrepreneurial careers and counselors with ownership and governance careers. From the perspective of family business research, these categories contain the elements of different family business life cycles and career paths of counselors.

The biographies served as the source of information for the research because they illustrated career construction in an institutional business elite. ${ }^{73}$ Prosopography, which is frequently employed in longitudinal historical studies at both geographic ${ }^{74}$ and individual levels, ${ }^{75}$ is useful for studying changes over time and trends during a specific time period $^{76}$ because the constructed prosopographical database contains the same variables for each individual. ${ }^{77}$ Collective information regarding the same group of individuals is characteristic of prosopography and prosopographical database construction. ${ }^{78}$ In prosopography, trends are

73. Barton, "Determinants of Economic Attitudes."

74. West, "Notes on Achaean Prosopography"; Lambkin, "Towards a Prosopography."

75. Bernstein, "Prosopography and the Career."

76. Mathisen, "The Prosopography."

77. Cunningham, "Innovators, Networks and Structures," 451.

78. Marttila, "Työ teollistumisen ja arjen rajapintana”, 77-78. 
analyzed by following individuals, who are identified by family name; ${ }^{79}$ in the present study, executives' family names were used. Once identities have been documented, variables such as educational level, ${ }^{80}$ careers, ${ }^{81}$ and membership in institutions ${ }^{82}$ are coded. Thus, a prosopographical approach provides historical information about individuals. ${ }^{83}$

In this study, the validity of the measurements used was based on the concepts defined by the theoretical framework. Membership in the institutional business elite was confirmed by the conferment of the honorary title of "counselor." However, because the data included only socially active and visible businesspersons who were recognized by society for their achievements and performance, small family business owners and managers were not represented the database, and information on family executives' career paths existed only for individuals in large or medium-sized family businesses. Moreover, the archives did not fully document their career paths, and the data available to the biographies' authors were often incomplete. Because of missing data, data for certain years and some of the executives' early duties were unavailable.

The reliability of prosopography can be undermined by the risk of "subjective judgement of importance," as the biographies' authors selected information and sources based on personal knowledge and subjective assumptions. ${ }^{84}$ The present study controlled for this risk by employing a similar framework for each biography and by using other biographies from the same project as exemplars of the authors' writing styles and data collection. However, counselors' lives and institutional business elite careers were unusually well documented in the available business histories and archives that formed the basis for the biographies, which made it possible to perform a quantitative prosopographical analysis for certain time periods and positions. ${ }^{85}$ This situation decreased the risk posed by missing, unrepresentative, or biased data. ${ }^{86}$ In each century, counselors' lives were well known and documented. Because accepting the title of counselor was voluntary and required the honored recipient to pay a fee, counselors provided only a limited and potentially unrepresentative sample of the institutional business elite in a particular country. The random sample thus limits

79. Keats-Rohan, "Biography, Identity and Names”; Ruggini, "Rome in Late Antiquity"; Albright, "Cuneiform Material."

80. McConica, "The Prosopography of the Tudor University."

81. Shapin and Thackray, "Prosopography as a Research Tool."

82. Spitzer, "Malicious Memories."

83. Barnish, "Late Roman Prosopography Reassessed,” 171; Bulst, "Prosopography and the Computer,”16.

84. Barman and Barman, "The Prosopography of the Brazilian Empire," 79.

85. Plamper, "The Russian Orthodox Episcopate."

86. Cohen, "Missing, Biased, and Unrepresentative." 
the generalizability of the data. ${ }^{87}$ However, the database used in the current study provided information about family firms that contributes to our knowledge of career path construction in family business executives who were members of an elite group over the course of several centuries. Studying counselors provided knowledge of the most socially active citizens; because counselors were nominated by associations, organizations, and individuals, a businessperson who was more active in society was more likely to be nominated for a counselorship.

Prosopographical research also risks underestimating the contributions of environmental and organizational factors by focusing on the unique achievements and contributions of individuals. ${ }^{88}$ Family firm executive career paths are based on organizational positions in family businesses and illustrate longevity and continuity due to the multigenerational management and ownership typical of family firms. This feature decreases the risk of prosopographical research neglecting organizational features because family business heritage influences daily business operations due to risk-averse organizational behaviors. ${ }^{89}$

Prosopography typically uses biographies to provide information regarding demographic characteristics of the individuals who are studied because of the positions they hold in society. ${ }^{90}$ Bourdieusian prosopography was employed in the present study because it focuses on individuals who are group members owing to their position or some other distinctive social feature that they exhibit. In Bourdieusian prosopography, the same framework is used to obtain information for each individual. In the present study, the same set of research questions was used to study counselors, and counselor biographies contained the same types of information. ${ }^{91}$ In this study, adopting a Bourdieusian prosopographical approach required the creation of an empirical database that provided measures of variables for counselors based on the information obtained from the primary and secondary documentation available. ${ }^{92}$

Based on these considerations, the present study adopted a Bourdieusian prosopographical approach to construct a database that made it possible to compare different cohorts in family firms and to identify the distinctive features of elite family business executives' careers. The remainder of the paper presents the results of the study, a discussion of the study findings, and study conclusions.

87. Kansikas, "The Business Elite in Finland: a Prosopographical Study of Family Firm Executives,” 5.

88. MacLeod and Nuvolari, "The Pitfalls of Prosopography,” 774.

89. Zellweger and Sieger, "Entrepreneurial Orientation," 80-81.

90. Verboven, Carlier, and Dumolyn, "A Short Manual," 9-10.

91. Broady, "French Prosopography," 381-382.

92. Bradley and Short, "Texts into Databases," 8. 


\section{Results}

The results of the study are presented in chronological order. The study focused on the career paths of family firm executives in the institutional business elite who were awarded the honorary title of counselor for their achievements, which included four types of counselors (see Table 1). The data were classified into six cohorts. The first cohort, "fathers and sons" (1762-1850), included the pioneer generation of family business executives. Most of these firms were run by second-generation family members, which illustrates the multigenerational nature of family firms from the outset.

This era of merchant capitalism was characterized by international trading and diversified business ideas among family and non-family firms. The state and governing officials had an influence on businesses though regulations and legislation. This era of capitalism was a hegemonic phase for family firms because private firms were run by business families, who had entrepreneurial career paths. ${ }^{93}$

As Finland became more industrialized, the second cohort, "industrial managers" (1851-1917), responded to the need for family

Table 1 Demographic characteristics of family executive counselors

\begin{tabular}{ccccc}
\hline Cohort & $\begin{array}{c}\text { Counselor of } \\
\text { Sales and Trade }\end{array}$ & $\begin{array}{c}\text { Counselor } \\
\text { of Mining }\end{array}$ & $\begin{array}{c}\text { Counselor of } \\
\text { Agriculture }^{96}\end{array}$ & $\begin{array}{c}\text { Counselor of Industry } \\
\text { and Commerce }^{97}\end{array}$ \\
\hline $1762-1850(\mathrm{~N})$ & 52 & 7 & 0 & 0 \\
Mean age & 66.7 & 63.1 & - & - \\
SD (age) & 10.89 & 13.35 & - & - \\
1851-1917 (N) & 83 & 6 & 4 & 0 \\
Mean age & 67.7 & 65.8 & 74.3 & - \\
SD (age) & 10.48 & 7.70 & 7.76 & - \\
1918-1945 (N) & 36 & 15 & 1 & 79.0 \\
Mean age & 73.4 & 74.4 & - & 6.42 \\
SD (age) & 9.52 & 10.58 & - & 7 \\
$1946-1959(\mathrm{~N})$ & 39 & 17 & 2 & 77.3 \\
Mean age & 76.5 & 73.7 & 80.0 & 7.16 \\
SD (age) & 9.89 & 11.77 & 1.41 & 39 \\
1960-1979 (N) & 55 & 14 & 0 & 78.1 \\
Mean age & 78.58 & 77.4 & - & 10.01 \\
SD (age) & 10.87 & 12.74 & - & 31 \\
1980-2010 (N) & 27 & 11 & 1 & 75.06 \\
Mean age & 75.5 & 74.6 & - & 7.55 \\
SD (age) & 10.14 & 9.014 & - & \\
\hline
\end{tabular}

93. Ojala and Karonen, "Business: Rooted in Social Capital over the Centuries," 101.

94. Kauppaneuvos (Finnish honorary title).

95. Vuorineuvos (Finnish honorary title).

96. Maanviljelyneuvos (Finnish honorary title).

97. Teollisuusneuvos (Finnish honorary title) and talousneuvos (Finnish honorary title; one person from the cohort 1918-1945). 
firms run by resource-based founder-generation family entrepreneurs. The context surrounding this cohort is one of industrialized capitalism, in which other types of private companies started to emerge alongside family businesses. This shift was caused not only through industrial development, but also through increases in funding and other types of available resources, which made capitalism more customer-oriented than ever before. ${ }^{98}$

The third cohort, "bankers" (1918-1945), was a group of family executives who were active in politics and banking and who responded to the needs of the newly formed Republic of Finland, which became independent in 1917. Financial capitalism, through close collaboration between the state and private firms, emerged. The size of the companies increased, and large family corporations, together with state-owned and privately owned non-family corporations, dominated some Finnish industries. ${ }^{99}$

The next three cohorts, the "first era of sales and industry" (19461959), the "second era of sales and industry" (1960-1979), and the "third era of sales and industry" (1980-2010), represented a period in which family firm executives incorporated both industry- and salesbased business ideas into their firms. National capitalism turned into global capitalism, through which international business operations have become the standard for high-performing and growth-oriented family firms. Diversification had previously been a dominant feature for family businesses, but the new competition changed the markets. Firms started to focus on core competencies and to gather more investments outside Finland. ${ }^{100}$ In modern times, family firm executives have been more involved in business governance instead of engaging in entrepreneurship. However, the number of foundergeneration family members remained high throughout the centuries studied. Most counselors were founder-generation members, apart from the first (1762-1850) and last (1980-2010) cohorts, which were dominated by the second generation. Third-, fourth-, and fifth-generation family members were unusual, but their number has increased in modern times.

\section{Data from Representative Family Firm Cases from Each Cohort}

Each counselor biography reflected its cultural and historical context. The first cohort, "fathers and sons” (1762-1850) included several

98. Ojala and Luoma-Aho, "Sidosryhmäsuhteet liiketoiminnan sosiaalisena pääomana merkantilismista globaalitalouteen,” 129.

99. Ojala and Karonen, "Business: Rooted in Social Capital over the Centuries," 110-112.

100. Ojala and Luoma-Aho, "Sidosryhmäsuhteet liiketoiminnan sosiaalisena pääomana merkantilismista globaalitalouteen," 132-133. 
self-made entrepreneurs who focused on sales and created career paths in trading. Johan Sederholm (1722-1805) ${ }^{101}$ was a counselor who was a representative self-made entrepreneur in the first cohort. From humble beginnings, he engaged in occasional work contracts and for longer periods as a trainee in sales companies; he then entered into a partnership and owned a trading company in Helsinki based on his network of contacts. Sederholm was a founder-generation serial entrepreneur who not only managed his own shops but also was a partner or major owner of a number of factories, shipyards, sawmills, and breweries. Some of the businesses were transferred to the next generation, who continued these family businesses.

Family control and heritage, as a common feature of family firms, influenced counselor career paths. Together with family control, the institutional role of established organizations influenced individual career development, as was the case for Counselor of Sales and Trade Peter Malm (1800-1868). ${ }^{102}$ Malm's family had been established in shipping and trade in the countries neighboring Finland for two generations. However, because Malm's father, Pehr Malm, went bankrupt, Peter did not share the financial advantages enjoyed by most established family firms. He focused on international trade and exports, focusing on British markets in particular. Malm's career path was that of an entrepreneur. He partnered in several Finnish sawmills, tobacco factories, and shipyards and also invested in British banks and the financial instruments they provided during the nineteenth century. Shipping goods between different market areas by cargo fleet was typical for Malm, who was active in recognizing new business opportunities. ${ }^{103}$ The family business was transferred to his son, Otto Malm, who also became a counselor.

Continuity in family businesses was based not only on firm performance but also on responses to historical and industrial challenges. Jean Bruun (1817-1872) ${ }^{104}$ belonged to the second cohort, "industrial managers," at the beginning of a period dominated by industryoriented family businesses. Because times were changing, some family firms in the institutional business elite faced pressures to change their business models. Bruun was a fourth-generation family business member who eventually went bankrupt and was forced to end the long-lasting family dynasty. He inherited a corporation in need of substantial investments; this corporation required a drastic turnaround strategy due to its poor profitability. The family did not remain in the institutional business elite as a result of long-delayed, overdue

101. Mäntylä and Mäkelä-Alitako, "Biography of Johan Sederholm.”

102. Hoffman, "Biography of Peter Malm."

103. Nikula, "Malmska Handelshuset i Jakobstad,” 348-349.

104. Yrjänä, "Biography of Jean Bruun." 
decisions regarding business operations and the development of radical industry changes. David Pulkkinen (1851-1925) ${ }^{105}$ was a counselor of sales and a founder-generation family entrepreneur who followed the career path of a self-made man. He began his career as a clerk in different trading companies and achieved the position of wholesale trader and ship owner, focusing on industrial ventures. $\mathrm{He}$ built and managed a sawmill, a local newspaper, a brewery, a brick factory, a tobacco factory, and a milling plant. His son continued the family business, David Pulkkinen Ltd., in the Mikkeli region, and had a substantial influence on local industrial development.

Wilhelm Sohlberg (1876-1938), ${ }^{106}$ who was a counselor of the third cohort, "bankers," was the CEO of Oy G.W. Sohlberg Ab Ltd. and the bank Luottopankki Ltd. He was a second-generation family member in the Sohlberg family business. His family's active role in the banking sector was inherited from his father and the founder of the family business, Gabriel Sohlberg, who played a role in the emergence of other banks, such as Kansallis-Osake-Pankki (KOP) and Vakuutusyhtiö Pohjola. Wilhelm Sohlberg earned an engineering degree and obtained work experience abroad before entering the family business. In addition to the family business, he also served as CEO of Luottopankki, a subsidiary of the KOP corporation, for five years. He was on the supervisory board of the KOP bank and held positions on the board of directors of other industrial companies and banks, such as Säästöpankki. Sohlberg's career as a counselor of mining focused on corporate connections, and he played an active role on the boards of the banks.

Paavo Kolehmainen (1866-1944) ${ }^{107}$ made his career as CEO of Riihimäki Lasi Oy Ltd., which was founded by his father, Mikko Kolehmainen, and H. G. Paloheimo. Kolehmainen was a secondgeneration family business member with an engineering degree. In addition to serving as CEO of Riihimäen Lasi Ltd., he was CEO of two other glass factories (Kauklahti and Ryttylä) and a window factory (Ikkuna Ltd.). In addition to the core family business, he served on the KOP supervisory board. His career path, which focused on the core family business and on positions exhibiting synergy with the glass industry, was typical. His son, Pentti Kolehmainen, continued the business as a third-generation family member.

R. Erik Serlachius (1901-1980), ${ }^{108}$ who was a member of the fourth cohort, the "first era of sales and industry," was CEO of G. A. Serlachius Oy Ltd. and a counselor of mining. He was a third-generation family

105. Luoma-Aho, "Biography of David Pulkkinen."

106. Vesikansa, "Biography of Wilhelm Sohlberg."

107. Määttä, "Biography of Aatu Kolehmainen."

108. Vesikansa, "Biography of R. Erik Serlachius." 
member who acquired experience and education abroad before entering the family business. Serlachius was a growth-oriented CEO; the corporation employed 4,300 persons and was listed on the stock exchange under his leadership. He also obtained revenues from the large forest estates that he owned in Finland. Serlachius had a visible social role during his career, serving on several commercial and professional commissions as well as on the boards of charities and nonprofit organizations. In the 1950s, he served as Minister of Logistics and Labor in the Finnish government and also as a chancellor of the orders. In addition to his social influence, he exhibited strong corporate connections in banking and several industrial companies through his role as board chairman and as a board member. Serlachius's career path provides an example of a counselor in a family business in the capital-intensive forest industry, which was important for the economy of Finland. The family business was transferred to the fourth generation when his son Gustaf Serlachius began to manage the family wealth.

Sven Fazer (1897-1985) ${ }^{109}$ was a second-generation family business member and CEO at Fazer Ltd. His father and the founder of the company, Karl Fazer, had been previously awarded the title of counselor. Sven Fazer worked in the family business for sixty-four years. He began as an assistant; after serving as CEO, he was chairman of the supervisory board and the board of directors at Fazer. Fazer Ltd. grew over the years and employed more than 2,000 persons under his management. He held board positions in the banking sector (Pohjoismaiden Yhdyspankki) and in the types of companies whose collaboration benefited Fazer, such as the sugar industry (Suomen Sokeri Ltd.). Fazer was also a board member in professional associations, the chamber of commerce, and the Swedish School of Business and Economics (Hanken). His son, Peter Fazer, continued the family business as a third-generation family member.

Arvi Tammivuori (1911-1972), ${ }^{110}$ a second-generation family member, was a counselor of industry and commerce in the fifth cohort, the "second era of sales and industry." He was CEO of UPO Ltd.; during his tenure, UPO expanded beyond the production of electronic equipment into the production of different types of plastic products. Tammivuori's innovative approach to production increased the product volume of UPO, adapting business strategies and product categories to changing market needs. By the end of his term as CEO, the company employed more than 3,000 people. Tammivuori's career began as a trainee in the family business. His career was entrepreneurial;

109. Hoffman, "Biography of Sven Fazer."

110. Hassinen, "Biography of Arvi Tammivuori." 
in addition to being CEO of UPO, he was CEO of Luottokassa Ltd., Sateenkaari Ltd., and U-Myynti Ltd., which promoted the strategy of the Asko corporation, the family business founded by his father. Both as a board member and as chairman of the board of directors, he participated in banking, media, and wood industry companies in the Lahti and Helsinki regions. His social influence involved funding Lahti regional sport teams and serving on the boards of professional industry associations.

Aarne Mustakallio (1909-1970)111, a counselor of mining and CEO of the Lahden Rautateollisuus Ltd., was a second-generation family business member. Mustakallio created a company that focused on international trade in machinery. He obtained a formal education and other work experience before entering into the family business. The family corporation consisted of companies of which Mustakallio was also CEO, which included Sopenkorpi Oy, Lahden Vaaka Oy, and Sopenkaluste Oy. As CEO of the family business, Mustakallio was locally active in Lahti politics, including the city council and city board, and was socially active in Lahti regional associations. His career path provides an example of an executive who focused on service to the family business and maintained the growth of the family business by importing and exporting technology internationally.

Krister Ahlström (1940- $)^{112}$ is a counselor who represents the most recent of the six cohorts, the "third era of sales and industry." $\mathrm{He}$ is a counselor of mining and was a director and chair of the board of directors of A. Ahlström Oy. Ahlström was a fourth-generation member of the family business. He forged a business career in the service of the Oy Wärtsilä Ab by eventually becoming vice CEO and a member of the board of directors. His international business career path was established prior to joining A. Ahlström Ltd., which employed more than 13,000 people in the late 1970s. In addition to family business responsibilities, Ahlström pursued a career in the governance of large corporations, such as Fortum PLC, Stora Enso PLC, and Nordea PLC, and large private companies, such as Oy Aga, Vakuutus Oy Sampo, and $\mathrm{ABB} \mathrm{Oy}$. Together with his career path in large non-family and family corporations, he exerted his social influence during his career, serving as a board member on Finnish and European professional industry boards and on the boards of research organizations, such as Åbo Akademi University, ETLA, and the Helsinki School of Economics. He was the chair of the Finnish Family Firms Association and the European Family Firms Association (GEEF).

111. Hassinen, "Biography of Aarne Mustakallio.”

112. Mansner, "Biography of Krister Ahlström." 
Maarit Toivanen-Koivisto (1954- ) ${ }^{113}$ is CEO of Onvest Ltd. She was awarded the first female counselorship of mining in Finland. ToivanenKoivisto is a fourth-generation member of the family business. She pursued a twenty-year career in the family business before becoming a member of the board of directors and CEO. Her career path included operational positions, such as sales secretary, buyer in different departments, sales manager, and quality manager, prior to obtaining strategic positions in governance and management in the large family corporation. Her experience, which began with work as an assistant, enabled her to develop the family business and to understand all parts of the organization. In addition to the family corporation, she has been a board member in large corporations, such as Rautaruukki PLC, PohjolaYhtymä PLC, Neste Oil PLC, Itella PLC, Tulikivi PLC, and Are Oy Ltd. She has also served as a board member for the chamber of the commerce, the Family Business Network, research funding associations, charitable organizations, and professional and industrial associations.

\section{Results of Counselor Career Paths}

Among family firm executives, the number of career positions as employees, managers, employers and firm governance positions tended to increase throughout the time period studied. On average, the number of positions held during the career of a member of the institutional business elite was 2.5 times higher at the end of the twentieth century than the number of positions held at the end of the eighteenth century. This change reflects increased hierarchical complexity and increased career mobility. However, throughout the time period studied, there were some family firm executives who held only two positions during their careers (see Table 2).

The initial positions held by family firm executives during their careers differed for the cohorts. The "fathers and sons" (1762-1850) and "industrial managers" (1851-1917) cohorts both consisted of founder- and second-generation family firm executives who initially worked as assistants. Typically, after a period of training, family firm members obtained positions as salesmen and ran their own companies. As in the first cohort, the career paths of "industrial managers" were more entrepreneurially oriented, and counselors typically had more managerial careers. This trend also reflects a historical setting in which the resources available, including funding, became more typical by 1917. The era of the merchant families was gone, and Finland needed industrial companies that were more customer- and production-oriented than the early family firms.

113. Valtonen, "Biography of Maarit Toivanen-Koivisto." 
Table 2 Number of career positions during institutional business elite careers ${ }^{114}$

\begin{tabular}{lccccc}
\hline Cohort & N (counselors) & Minimum & Maximum & Mean & SD \\
\hline $1762-1850$ & 58 & 1 & 22 & 6.48 & 3.885 \\
$1851-1917$ & 93 & 2 & 22 & 8.22 & 4.318 \\
$1918-1945$ & 58 & 3 & 25 & 12.69 & 5.871 \\
$1946-1959$ & 65 & 3 & 32 & 13.74 & 6.915 \\
$1960-1979$ & 111 & 2 & 33 & 12.07 & 5.983 \\
$1980-2010$ & 70 & 2 & 33 & 15.39 & 7.801 \\
\hline
\end{tabular}

The early career stages for the "bankers" cohort (1918-1945) differed from those of the two earlier cohorts. These family firm executives began their careers as accountants and bookkeepers, which presaged future positions as founders of local bank offices and as board members and chairs of local and national bank boards. Following their bookkeeping positions, they typically became CEOs. The era of financial capitalism characterized this cohort, which increased counselor responsibilities in the banking sector. Career paths became increasingly professionalized in family firms, meaning that instead of entrepreneurial careers, counselors generally had career positions in management and in governance of these growing organizations.

The positions held bythe "first era of sales and industry" cohort (1946-1959) reflected the increasing number of corporate governance duties in family firms. Some family executives were employed as CEOs and chaired the board of directors at the onset of their careers, whereas others began in assistant positions as trainees. The "second era of sales and industry" (1960-1979) and the "third era of sales and industry" (1980-2010) cohorts indicate changes in family executives' early career paths because these individuals began their careers in management positions, such as sales managers, product managers, or production managers (see Table 3). These cohorts represent the change from national capitalism to a more globally oriented context. Careers in large enterprises were predominantly internationally oriented, and the role of the family members was focused on the governance and ownership of businesses. The next generation's members were typically trained in junior management positions, such as product managers, to join the family business. The global development increased international competition, which has also shifted counselors' career paths toward more internationally oriented business responsibilities. On average, careers in the first five cohorts lasted from forty-eight to fifty-four years. However, careers in the most recent cohort (1980-2010) lasted an average of only forty-three years

114. There were 10 counselors for whom the number of career positions was unknown; these counselors were not included in the table. 
Table 3 The first occupational titles during institutional business elite careers (a) Entrepreneurial and managerial job roles

\begin{tabular}{|c|c|c|c|c|c|c|}
\hline & 1762-1850 & 1851-1917 & 1918-1945 & 1946-1959 & 1960-1979 & 1980-2010 \\
\hline \multirow{4}{*}{$\begin{array}{l}\text { Assistant, } \\
\text { clerk }\end{array}$} & 1. $50 \%(28)$ & $1.50 \%(46)$ & 1. $23 \%(13)$ & $1.37 \%(24)$ & 1. $17 \%(19)$ & $1.4 \%(3)$ \\
\hline & $2.13 \%(7)$ & 2. $9 \%(8)$ & 2. $7 \%(4)$ & 2. $12 \%(8)$ & $2.6 \%(7)$ & 2. - \\
\hline & 3. $2 \%(1)$ & 3. $3 \%(3)$ & 3. $2 \%(1)$ & $3.3 \%(2)$ & 3. $1 \%(1)$ & $3.1 \%(1)$ \\
\hline & 4. - & 4. - & 4. - & 4. $3 \%(2)$ & 4. - & 4. - \\
\hline \multirow{4}{*}{$\begin{array}{l}\text { Accountant, } \\
\text { bookkeeper }\end{array}$} & $1.9 \%$ & 1.15 & 1. $53 \%$ & 1. $21,5 \%(14)$ & $1.8 \%(9)$ & 1. $1 \%(1)$ \\
\hline & $2.11 \%(6)$ & 2. $25 \%(23)$ & 2. $41 \%(24)$ & $2.11 \%(7)$ & 2. $9 \%(10)$ & 2. - \\
\hline & 3. $4 \%(2)$ & 3. $11 \%(10)$ & 3. $17 \%(10)$ & $3.5 \%(3)$ & 3. $4 \%(4)$ & 3. - \\
\hline & 4. $4 \%(2)$ & 4. $4 \%(3)$ & 4. $9 \%(5)$ & 4. $2 \%(1)$ & 4. $2 \%(2)$ & 4. $3 \%(2)$ \\
\hline \multirow{4}{*}{$\begin{array}{l}\text { Trader and } \\
\text { salesperson }\end{array}$} & 1. $30 \%$ & 1. $16 \%(15)$ & $1.5 \%(3)$ & $1.5 \%$ & 1. $11 \%(12)$ & $1.9 \%(6)$ \\
\hline & $2.48 \%(27)$ & 2. $29 \%(27)$ & $2.14 \%(8)$ & 2. $17 \%(11)$ & 2. $10 \%(11)$ & $2.10 \%(7)$ \\
\hline & 3. 43\% (23) & 3. $23 \%(21)$ & & $3.11 \%(7)$ & 3. $9 \%(10)$ & $3.12 \%(8)$ \\
\hline & 4. $33 \%(15)$ & 4. $18 \%(15)$ & 4. $16 \%(9)$ & 4. $8 \%(5)$ & 4. $7 \%(7)$ & 4. $6 \%(4)$ \\
\hline \multirow{4}{*}{$\begin{array}{c}\text { Shop/estate } \\
\text { business } \\
\text { owner }\end{array}$} & 1. $2 \%(1)$ & 1. $4 \%(4)$ & 1. $2 \%(1)$ & 1. $2 \%(1)$ & 1. $5 \%(5)$ & 1. $1 \%(1)$ \\
\hline & 2. $9 \%(5)$ & 2. $13 \%(12)$ & 2. $14 \%(8)$ & 2. $3 \%(2)$ & 2. $5 \%(6)$ & $2.11 \%(8)$ \\
\hline & 3. $17 \%(9)$ & 3. $31 \%(28)$ & $3.9 \%(5)$ & 3. $2 \%(1)$ & $3.6 \%(6)$ & 3. $7 \%(5)$ \\
\hline & 4. $27 \%(12)$ & 4. $38 \%(31)$ & 4. $7 \%(4)$ & 4. $11 \%(7)$ & 4. - & 4. $10 \%(7)$ \\
\hline \multirow[t]{4}{*}{ Other } & 1. $9 \%(5)$ & 1. $4 \%(4)$ & 1. $11 \%(6)$ & 1. $31 \%(20)$ & 1. $46 \%(51)$ & 1. $74 \%(52)$ \\
\hline & $2.9 \%(5)$ & 2. $2 \%(2)$ & $2.9 \%(5)$ & $2.22 \%(14)$ & 2. $39 \%(43)$ & 2. $40 \%(28)$ \\
\hline & 3. $25 \%(13)$ & 3. $7 \%(6)$ & 3. $3 \%(2)$ & 3. - & 3. $33 \%(36)$ & ) $3.36 \%(25)$ \\
\hline & 4. $13 \%(6)$ & 4. $6 \%(5)$ & 4. $2 \%(1)$ & 4. $20 \%(13)$ & 4. $30 \%(32)$ & ) $4.19 \%(13)$ \\
\hline
\end{tabular}

(b) CEO and governance roles

\begin{tabular}{|c|c|c|c|c|c|c|}
\hline & $1762-1850$ & 1851-1917 & 1918-1945 & 1946-1959 & 1960-1979 & 1980-2010 \\
\hline \multirow{4}{*}{$\begin{array}{l}\text { Company } \\
\text { shareholder }\end{array}$} & $1 .^{\mathrm{a}}-$ & $1.8 \%(7)$ & 1. - & 1. - & 1. $5 \%(5)$ & 1. $9 \%(6)$ \\
\hline & $2.11 \%(6)$ & 2. $11 \%(10)$ & $2.3 \%(2)$ & $2.6 \%(4)$ & $2.6 \%(7)$ & 2. $10 \%(7)$ \\
\hline & $3.9 \%(5)$ & 3. $12 \%(11)$ & $3.5 \%(3)$ & 3. $5 \%(3)$ & 3. $8 \%(9)$ & $3.12 \%(8)$ \\
\hline & 4. $22 \%(10)$ & 4. $23 \%(19)$ & 4. $11 \%(6)$ & 4. $2 \%(1)$ & 4. $7 \%(7)$ & 4. $9 \%(6)$ \\
\hline \multirow[t]{4}{*}{ CEO } & 1. - & 1. $3 \%(3)$ & 1. $5 \%(3)$ & 1. $5 \%(3)$ & 1. $5 \%(6)$ & 1. $1 \%(1)$ \\
\hline & 2. - & 2. $11 \%(10)$ & 2. $17 \%(10)$ & 2. $15 \%(10)$ & $2.17 \%(19)$ & $2.21 \%(15)$ \\
\hline & 3. - & 3. $10 \%(9)$ & 3. $36 \%(21)$ & $3.37 \%(24)$ & 3. $29 \%$ & $3.9 \%(6)$ \\
\hline & 4. - & 4. $6 \%(5)$ & 4. $34 \%(19)$ & 4. $17 \%(11)$ & 4. $20 \%$ & 4. $24 \%(16)$ \\
\hline \multirow{4}{*}{$\begin{array}{l}\text { Member of } \\
\text { the board }\end{array}$} & 1. - & 1. - & 1. $2 \%(1)$ & 1. - & 1. $3(3 \%)$ & 1. - \\
\hline & 2. - & 2. $1 \%(1)$ & 2. $2 \%(1)$ & 2. $11 \%(7)$ & 2. $4 \%(4)$ & 2. $3 \%(2)$ \\
\hline & 3. - & 3.1 (1\%) & $3.5 \%(3)$ & $3.6 \%(4)$ & 3. $1 \%(1)$ & $3.12 \%(8)$ \\
\hline & 4. - & 4. $4 \%(3)$ & 4. $11 \%(6)$ & 4. $17 \%(11)$ & 4. $7 \%(8)$ & 4. $10 \%(7)$ \\
\hline \multirow{4}{*}{$\begin{array}{l}\text { Chairman of } \\
\text { the board }\end{array}$} & 1. - & 1. - & 1. - & 1. - & 1. $1 \%(1)$ & 1. - \\
\hline & 2. - & 2. - & 2. - & 2. $3 \%(2)$ & 2. $4 \%(4)$ & 2. $4 \%(3)$ \\
\hline & 3. - & 3. $2 \%(2)$ & $3.5 \%(3)$ & $3.9 \%(6)$ & 3. $10 \%(11)$ & $3.12 \%(8)$ \\
\hline & 4. - & 4. $1 \%(1)$ & 4. $11 \%(6)$ & 4. $20 \%(13)$ & 4. $13 \%(14)$ & 4. $19 \%(13)$ \\
\hline
\end{tabular}

\footnotetext{
a These numbers indicate the percentage of counselors who had this position as the first job in their careers, the second job, and so on.
}

and exhibited the lowest standard deviation, which indicates less variability in the careers of this cohort's institutional business elite members. The average number of service years after the counselor title was awarded ranged from thirty-one to thirty-eight years. The pioneering cohorts, 1762-1850 and 1851-1917, received their counselor titles earlier than their counterparts in other cohorts. For the most recent 
cohort, the standard deviation of the age at which the title of counselor was awarded decreased, which indicates cohesion in the length of a cohort member's career (see Table 4).

The cohorts differed with respect to the number of career positions held during their careers. Compared with the founder generation, next-generation family firm executives held fewer career positions. This trend began to change in the 1960s, with first-, second-, and third-generation family firm executives holding more management and governance positions than did founder-generation family members. This increase in the number of positions held reflects the increasing complexity of career paths and the increase in governance positions in family businesses (see Table 5).

On average, members of each generation's institutional business elite enjoyed long careers, ranging from 40 to 50 years, although there were differences for the 1918-1945, 1946-1959, and 1980-2010 cohorts. During these periods, the careers of next-generation family executives were shorter than the careers of individuals in the founder generation, with later generations having shorter careers. The careers of nextgeneration family firm executives from 1918 to 1959 were shorter, which suggests that the career paths of family business executives benefited from the resources accumulated by the earlier generation (see Table 6).

The length of time before being awarded the title of counselor was shorter for next-generation family executives than for individuals in the founder generation. The founder generation achieved the honorary title of counselor in approximately 35 to 40 years, whereas next-generation family members achieved the honorary title in 15 to 30 years, on average. This finding suggests that the family's existing business and capital enabled next-generation family members to succeed more rapidly (see Table 7 ).

Table 4 Institutional business elite career lengths and career lengths at the time that the title of "counselor" was awarded"115

\begin{tabular}{lcccccc}
\hline & 1762-1850 & 1851-1917 & 1918-1945 & 1946-1959 & 1960-1979 & 1980-2010 \\
\hline \multicolumn{2}{l}{ Service years } \\
$\mathrm{N}$ & 35 & 72 & 57 & 62 & 102 & 32 \\
Mean & 47.5 & 47.5 & 53.5 & 54.0 & 51.7 & 43.0 \\
SD & 15.069 & 11.423 & 10.986 & 11.048 & 11.934 & 7.135 \\
Service & years at the time that the title of “counselor" was awarded & \\
N & 36 & 72 & 56 & 63 & 108 & 69 \\
Mean & 30.8 & 31.6 & 36.3 & 37.7 & 35.4 & 34.1 \\
SD & 13.728 & 10.471 & 10.774 & 10.105 & 8.232 & 7.131 \\
\hline
\end{tabular}

115. There were 105 counselors whose total career length was unknown and 52 counselors whose total career length after receiving the counselorship was unknown; these counselors were not included in the table. 
Table 5 Institutional business elite career positions in family firms for different generations

\begin{tabular}{lccccccc}
\hline & $1762-1850$ & $1851-1917$ & $1918-1945$ & $1946-1959$ & $1960-1979$ & $1980-2010$ \\
\hline Founder gen & $(19 ; 7.8)$ & $(37 ; 9.67)$ & $(29 ; 14.3)$ & $(41 ; 13.56)$ & $(66 ; 10.93)$ & $(26 ; 12.3)$ \\
$1^{\text {st }}$ gen & $(31 ; 5.7)$ & $(41 ; 7.63)$ & $(20 ; 10.85)$ & $(20 ; 14.3)$ & $(33 ; 12.06)$ & $(29 ; 17.48)$ \\
$2^{\text {nd }}$ gen & $(6 ; 6.0)$ & $(10 ; 5.6)$ & $(3 ; 16.0)$ & $(3 ; 11.0)$ & $(10 ; 13.7)$ & $(9 ; 14.55)$ \\
$3^{\text {rd }}$ gen & - & $(4 ; 6.5)$ & $(4 ; 10.0)$ & $(1 ;-)$ & - & $(5 ; 20.0)$ \\
$4^{\text {th }}$ gen & - & - & - & - & $(1 ;-)$ & - \\
\hline
\end{tabular}

$(\mathrm{N}=$ family executives; mean $)$

\section{Discussion}

The study findings contribute to the current literature on business elites in a number of ways. However, the study, which adopted a Bourdieusian prosopographical approach, has several limitations. The number of individual careers in the analysis was limited because some information, such as the number of years in an individual's career, was not available. Additionally, the ability to achieve the goal of Bourdieusian prosopography and to examine individuals' lives over hundreds of years was limited by the archives and secondary data available to the biographies' authors. Because the study focused on Finnish family firms, study findings might not be generalizable to family firms worldwide. However, it should be noted that many of the family firms engaged in international business throughout the period studied and actively traded in the St. Petersburg area ${ }^{116}$ and other European ports, ${ }^{117}$ including in the Baltic Sea area.

The present study indicates that the careers of contemporary family firm executives are more complex than the careers of their counterparts in the eighteenth, nineteenth, and early twentieth centuries. This finding is consistent with Fellman's findings ${ }^{118}$ regarding industrial manager

Table 6 Institutional business elite career lengths in family firms for different generations

\begin{tabular}{lccccccc}
\hline & $1762-1850$ & $1851-1917$ & $1918-1945$ & $1946-1959$ & $1960-1979$ & $1980-2010$ \\
\hline Founder gen & $(12 ; 50.6)$ & $(33 ; 51.3)$ & $(28 ; 55.64)$ & $(38 ; 51.36)$ & $(61 ; 54.21)$ & $(14 ; 46.14)$ \\
$1^{\text {st }}$ gen & $(19 ; 44.73)$ & $(30 ; 42.86)$ & $(20 ; 53.65)$ & $(20 ; 46.2)$ & $(29 ; 46.51)$ & $(10 ; 40.7)$ \\
$2^{\text {nd }}$ gen & $(2 ; 50.0)$ & $(8 ; 50.87)$ & $(3 ; 45.0)$ & $(3 ; 41.3)$ & $(10 ; 50.9)$ & $(4 ; 43.5)$ \\
$3^{\text {rd }}$ gen & - & $(2 ; 41.5)$ & $(4 ; 39.75)$ & $(1 ;-)$ & - & $(3 ; 36.0)$ \\
$4^{\text {th }}$ gen & - & - & - & - & $(1 ;-)$ & - \\
\hline \multicolumn{2}{l}{$\mathrm{N}=$ family executives; mean $)$} & & & & &
\end{tabular}

116. Kuisma, "Metsäteollisuuden maa," 78.

117. Hjerppe and Jalava, "Economic Growth and Structural Change," 35.

118. Fellman, Uppkomsten av en Ddirektörsprofession,160-162. 
Table 7 Institutional business elite career lengths at the time that the counselor title was awarded to different generations in family firms

\begin{tabular}{|c|c|c|c|c|c|c|}
\hline & $1762-1850$ & 1851-1917 & 1918-1945 & 1946-1959 & 1960-1979 & 1980-2010 \\
\hline r gen & $(13 ; 36.38)$ & $(33 ; 37.06)$ & $(28 ; 37.85)$ & $(39 ; 41.84)$ & $(64 ; 36.68)$ & $(26 ; 38.34)$ \\
\hline $1^{\text {st }}$ gen & $(19 ; 27.73)$ & $(30 ; 25.23)$ & $(20 ; 37.3)$ & $(20 ; 32.2)$ & $(32 ; 33.15)$ & $(28 ; 32.5)$ \\
\hline $2^{\text {nd }}$ gen & $(2 ; 21.5)$ & $(8 ; 32.62)$ & $(2 ; 25.0)$ & $(3 ; 22.66)$ & $(10 ; 34.4)$ & $(9 ; 30.55)$ \\
\hline $3^{\text {rd }}$ gen & - & $(2 ; 15.5)$ & $(2 ; 27.5)$ & $(1 ;-)$ & - & $(5 ; 30.2)$ \\
\hline $4^{\text {th }}$ gen & - & - & - & - & $(1 ;-)$ & - \\
\hline
\end{tabular}

$(\mathrm{N}=$ family executives; mean)

career paths in Finland. However, in contrast to her results, the present study found that the length of family firm executive careers varied for different cohorts, averaging from forty-three years to fifty-four years.

Although some researchers have reported a decline in social cohesion among institutional business elites, ${ }^{119}$ the increasing number of second- and third-generation family firm executives in modern times indicates that Finnish family firms have not shared in this decline. Continuity and family control characterize social cohesion in family firms. Both the first (1762-1850) cohort and later cohorts included next-generation family executives who were members of the institutional business elite, which demonstrates that family firms are multigenerational organizations. Power in business accumulates into the hands of an elite group, ${ }^{120}$ and, in the case of the family firms, resource accumulation might mean that next-generation family members are awarded the title of counselor. In the institutional business elite studied, the members of later generations received benefits earlier than preceding generations. Although family firms in an institutional business elite do not form a homogenous class in society, they constitute a unique group of established and socially active business organizations.

Currently, careers are often based on self-employment and entrepreneurship. ${ }^{121}$ However, the current study did not find an increase in the number of founder-generation family executives over time. Foundergeneration family executives and entrepreneurs who began their own businesses were found in each cohort throughout the centuries. However, the presence of next-generation family executives in the cohorts also revealed that the resources accumulated by family firms influenced the career construction of institutional business elite members.

There were a number of differences in the career paths of different cohorts of family firm executives (see Table 8). The number of career

119. Heemskerk and Fennema, "Network Dynamics," 826.

120. Maclean, Harvey and Kling, "Pathways to Power."

121. Sullivan and Baruch, "Advances in Career Theory," 1563; Patzelt and Shepherd, "Negative Emotions." 
Table 8 Career paths of elite family business executives

\begin{tabular}{|c|c|c|c|c|c|}
\hline Cohort of Counselors/Variable & $\begin{array}{l}\text { Number of } \\
\text { Career Positions }\end{array}$ & Career Path Onset & Type of Career Path & $\begin{array}{l}\text { Counselor Title Earlier } \\
\text { for the Next-generation } \\
\text { than Founder-generation } \\
\text { Members }\end{array}$ & $\begin{array}{l}\text { Fewer Career Positions } \\
\text { among Next-generation vs. } \\
\text { Founder-generation } \\
\text { Members }\end{array}$ \\
\hline $\begin{array}{l}\text { 1762-1850 } \\
\text { "Fathers and sons" }\end{array}$ & Low & Traders and salesmen & Medium length & Yes & Yes \\
\hline $\begin{array}{l}\text { 1851-1917 } \\
\text { "Industrial managers" }\end{array}$ & Low & $\begin{array}{l}\text { Business owners and } \\
\text { assistants }\end{array}$ & Medium length & Yes & Yes \\
\hline $\begin{array}{l}\text { 1918-1945 } \\
\text { "Bankers" }\end{array}$ & Moderate & Accountants and CEOs & The longest & Yes & - \\
\hline $\begin{array}{l}\text { 1946-1959 } \\
\text { "First era of sales and industry" }\end{array}$ & High & $\begin{array}{l}\text { CEOs, middle-level managers, } \\
\text { and assistants; an } \\
\text { increasing number of } \\
\text { governance positions }\end{array}$ & The longest & Yes & - \\
\hline $\begin{array}{l}\text { 1960-1979 } \\
\text { "'Second era of sales and industry" }\end{array}$ & Moderate & $\begin{array}{l}\text { Middle managers, CEOs, and } \\
\text { governance positions }\end{array}$ & The longest & Yes & No, the reverse \\
\hline $\begin{array}{l}\text { 1980-2010 } \\
\text { "Third era of sales and industry" }\end{array}$ & High & $\begin{array}{l}\text { Middle managers and } \\
\text { governance positions }\end{array}$ & The shortest & Yes & No, the reverse \\
\hline
\end{tabular}


positions held by an individual increased over time, and the onset of career paths became more complex. The most recent three cohorts included family executives who held governance positions as chair of boards of directors early in their careers. The career paths of the members of these cohorts contrasted with the career paths of individuals in the 1762-1850 and 1851-1917 cohorts, who tended to begin their careers as traders and shopkeepers. Obtaining leading governance positions early in one's career is consistent with the findings of Useem and McCormack, ${ }^{122}$ who found that management and governance positions were characteristic of the career paths of institutional business elite members. Together with resource accumulation, these findings reflect the emergence of governance mechanisms in twentiethcentury society.

The lengths of career paths differed among the cohorts. Family firm executives in the 1980-2010 cohort had the shortest careers. However, in the two most recent cohorts, the number of career positions was higher for next-generation family executives compared with founder-generation executives. The early cohorts of the eighteenth and nineteenth centuries exhibited the opposite trend because the career paths of the founder generation were more diverse.

The results of the present study confirm the findings of Karonen's study of Finnish business managers from 1600 to $1920 .{ }^{123}$ Most business managers under Swedish rule (which lasted until 1809) were merchants, and the same was true for the family firms examined in the present research. In addition, the number of business managers who were merchants began to decrease during the nineteenth century in Finland; the present study also found that a similar decrease occurred among family firm executives in the "industrial managers" cohort (1851-1917).

The career paths of members of the Finnish institutional business elite became more complex over the time period studied. Nextgeneration family members were more likely to pursue a career outside the family business to obtain the experience needed for a career within the institutional business elite. The career construction of institutional business elite members was characterized by an increasing number of professional positions during an individual's career. For family firm executives in the institutional business elite, career construction involves a career path in which the individual obtains increasingly higher positions in the corporation. Obtaining a governance position early in one's career is a distinctive feature of twentieth-century family firms. Because governance is a sign of power in business, such positions reveal the elite status of these family firm executives.

122. Useem and McCormack, "The Dominant Segment."

123. Karonen, "Patruunat ja politiikot." 


\section{Conclusion}

In the eighteenth century, family firms in the original institutional business elite created careers in Sweden, which governed Finland until 1809. Although Finland became an autonomous province of Russia in 1809, this change did not affect the formation of the institutional business elite, who were able to continue their businesses under the same circumstances, with the same language, legislation, and family ownership. This continuity is evident in the data, which indicate that the same type of family firms (i.e., trading families) belonged to the institutional business elite before and after 1809. Family firm executives were likely to hold fewer career positions during their careers. The title of "counselor" was awarded to next-generation family members earlier than it was to pioneering founder-generation family members. The tendency for families to be sales-oriented and entrepreneurial began to change toward the end of the nineteenth century, as nationalism emerged in European countries.

The industrialization of Finland, which began in the 1850s, increased the number of industry-based businesses and families investing in different industries. The same period saw legislative reforms in the autonomous province of Finland that included postal system reforms and the adoption of a Finnish currency. ${ }^{124}$ Autonomy enabled Finland to create its own legislation, currency, post offices, language, school systems and taxation until the end of the nineteenth century, when czarist Russia began to experience economic, nationalist, and revolutionary challenges. Because of significant political pressures to reduce Finnish autonomy, Finland began to lose its status as an autonomous province. The Finnish language became more common in business, and Finnish-speaking families started becoming members of the institutional business elite. Finland obtained its independence in 1917 after the Russian Revolution, and a socially active institutional business elite emerged. In addition to political activity, banking became a typical feature in the careers of members of the institutional business elite. The increasing number of governance positions in family firm executive career paths reveals the accumulation of social power. Political and business activities that included both banking and governance positions made this cohort of family firm executives powerful individuals in their localities. Within the business environment, decision-making power was highly centralised although Finland was a democratic republic.

In comparison with other European economies such as Sweden, Finnish family firms suffered from greater instability than Swedish

124. Hjerppe, “The Finnish Economy 1860-1985," 19. 
family firms during the twentieth century, although Finland was more politically stable than Italy, where politics influenced family firms. ${ }^{125}$ The career paths of family executives occurred in the historical context in which the family firms operated. These paths were influenced by economic development as well as wars, politics, and business competition. The institutional business elite in Finland did not face the disruption created by revolution and civil war in Russia during the early twentieth century. Instead, throughout the cohorts, single-family firms exhibited continuity. The role of family business founders, a visible group of family executives in each cohort, demonstrates the need for self-made entrepreneurs in the formation and establishment of an institutional business elite. Future studies investigating the development of institutional business elites should integrate archival data with case studies to provide a more detailed explanation of the circumstances in which family businesses in institutional business elites survive or leave the market.

Family firms made distinct contributions to the career paths of executives in the institutional business elite. The honorary title of counselor, which was never inherited, was awarded selectively based on individual economic and social achievements. However, the title of counselor was awarded earlier to next-generation family executives than to founder-generation executives. Next-generation family executives achieved career status in the institutional business elite more rapidly than individuals in the founder generation for each cohort from 1762 to 2010. Future studies might statistically analyze this information to increase our knowledge of the acceleration of career construction experienced by executives of long-lasting family firms.

Bibliography of Works Cited

\section{Books}

Arthur, Michael B. and Denise M. Rousseau. The Boundaryless Career: A New Employment Principle for a New Organizational Era. New York: Oxford University Press, 1996.

Colli, Andrea. The History of Family Business, 1850-2000. Cambridge: Cambridge University Press, 2006.

Fellman, Susanna. Uppkomsten av en Ddirektörsprofession: Industriledarnas Utbildning och Karriär I Finland 1900-1975. Bidrag till Kännedom av Finlands Natur och Folk. Nr. 155, Helsingfors: Finska Vetenskaps-Societen, 2000 .

125. Colli and Larsson, "Family Business and Business History," 49. 
Heckscher, Eli F. Sveriges ekonomiska historia från Gustav Vasa. Andra delen. Den moderna Sveriges Grundläggning, II:2. Stockholm: Albert Bonniers Förlag, 1949.

Hjerppe, Riitta. The Finnish Economy 1860-1985: Growth and Structural Change. Helsinki: Bank of Finland, 1989.

Kallioinen, Mika. Verkostoitu tieto: informaatio ja ulkomaiset markkinat Dahlströmin kauppahuoneen liiketoiminnassa 1800-luvulla. Helsinki: Suomalaisen Kirjallisuuden Seura, 2002.

Karonen, Petri. Patruunat ja poliitikot: yritysjohtajat taloudellisina ja poliittisina toimijoina Suomessa 1600-1920, Helsinki: Suomalaisen Kirjallisuuden Seura, 2004.

Kuisma, Markku. Metsäteollisuuden maa. Suomi, metsät ja kansainvälinen järjestelmä 1620-1920. Jyväskylä, Finland: Suomalaisen Kirjallisuuden Seura, 1993.

Marttila, Juuso. Työ teollistumisen ja arjen rajapintana: Strömforsin ja Ramnäsin rautaruukkiyhteisöt 1880-1950. Doctoral dissertation, University of Jyväskylä, Finland. Helsinki: Työväen historian ja perinteen tutkimuksen seura, 2014.

Müller, Leos. The Merchant Houses of Stockholm, c. 1640-1800. A Comparative Study of Early-Modern Entrepreneurial Behaviour. Uppsala, Sweden: Uppsala University, 1998.

Nikula, Oscar. Malmska Handelshuset in Jakobstad, Helsingfors, Sweden: Svenska Litteratursällskapet i Finland, 1948.

Poza, Ernesto. Family Business. London: Cengage Learning, 2009.

\section{Articles, Papers, and Book Chapters}

Albright, W. F. "Cuneiform Material for Egyptian Prosopography 1500-1200 B.C.” Journal of Near Eastern Studies 5 (1946): 7-25.

Andrle, Vladimir. "The Buoyant Class: Bourgeois Family Lineage in the Life Stories of Czech Institutional Business Elite Persons." Sociology 35 (2001): 815-833.

Barman, Roderick and Jean Barman. "The Prosopography of the Brazilian Empire.” Latin American Research Review 13 (1978): 78-87.

Barnish, S. J. B. "Late Roman Prosopography Reassessed." The Journal of Roman Studies 84 (1994): 171-177.

Barton, Allen H. "Determinants of Economics Attitudes in the American Institutional Business Elite." American Journal of Sociology 91 (July 1985): 54-87.

Bernstein, Alvin H. "Prosopography and the Career of Publius Mucius Scaevola." Classical Philology 67 (January 1972): 42-46.

Biemann, Torsten, Annette Eva Fasang, and Daniela Grunow. "Do Economic Globalization and Industry Growth Destabilize Careers? An Analysis of Career Complexity and Career Patterns over Time." Organization Studies 32 (2011): 1639-1663.

Boyd, Robert L. "Transformation of the Black Institutional Business Elite." Social Science Quarterly 87 (2006): 602-617.

Bradley, John and Harold Short. "Texts into Databases: The Evolving Field of New-Style Prosopography," Literary and Linguistic Computing 20 (Suppl 2005): 3-24. 
Broady, Donald. "French Prosopography: Definition and Suggested Readings." Poetics 30 (2002): 381-385.

Bulst, Neithard. "Prosopography and the Computer: Problems and Possibilities." In History and Computing II, edited by Peter Denley, Stefan Folgelvik, and Charles Harvey, 12-18. Manchester: Manchester University Press, 1989.

Carless, Sally A. and Jessica L. Arnup. "A Longitudinal Study of the Determinants and Outcomes of Career Change." Journal of Vocational Behavior 78 (2011): 80-91.

Chudzikowski, Katharina. "Career Transitions and Career Success in the 'New' Career Era.” Journal of Vocational Behavior 81 (2012): 298-306.

Chudzikowski, Katharina and Wolfgang Mayrhofer. "In Search of the Blue Flower? Grand Social Theories and Career Research: The Case of Bourdieu's Theory of Practice." Human Relations 64 (2011): 19-36.

Chung, Chi-Nien and Xiaowei R. Luo. "Leadership Succession and Firm Performance in an Emerging Economy: Successor Origin, Relational Embeddedness, and Legitimacy." Strategic Management Journal 34 (2013): 338-357.

Clark, Ed and Anna Soulsby. "The Re-formation of the Managerial Elite in the Czech Republic.” Europe-Asia Studies 48 (1996): 285-303.

Cohen, Gidon. "Missing, Biased, and Unrepresentative. The Quantitative Analysis of Multisource Biographical Data." Historical Methods 35 (2002): 166-176.

Colli, Andrea. "Contextualizing Performances of Family Firms: The Perspective of Business History." Family Business Review 25 (2012): 243-257.

Colli, Andrea and Mats Larsson. "Family Business and Business History: An Example of Comparative Research." Business History 56 (2014): 37-53.

Cunningham, Peter. "Innovators, Networks and Structures: Towards a Prosopography of Progressivism." History of Education 30 (2001): 433-451.

Ellersgaard, Christoph H., Anton G. Larsen, and Martin D. Munk. "A Very Economic Elite: The Case of the Danish Top CEOs.” Sociology 47 (2012): 1051-1071.

Fadjukoff, Paivi, Katja Kokko, and Lea Pulkkinen. "Changing Economic Conditions and Identity Formation in Adulthood." European Psychologist 15 (2010): 293-303.

Feldman, Daniel C., and Thomas W. H. Ng. "Careers: Mobility, Embeddedness, and Success." Journal of Management 33 (2007): 350-377.

Fellman, Susanna. "Prosopographic Studies of Business Leaders for Understanding Industrial and Corporate Change.” Business History 56 (2014): 5-21.

Flemmen, Magne. "Putting Bourdieu to Work for Class Analysis: Reflections on Some Recent Contributions." The British Journal of Sociology 64 (2013): 325-343.

— . "The Structure of the Upper Class: A Social Space Approach." Sociology 46 (2012): 1039-1058.

Friedman, Walter and Richard Tedlow. "Statistical Portraits of American Institutional Business Elites: A Review Essay.” Business History 45 (2003): 89-113.

Ginalski, Stephanie. "Can Families Resist Managerial and Financial Revolutions? Swiss Family Firms in the Twentieth Century." Business History 55 (2013): 981-1000. 
Goodman, Paul. "Ethics and Enterprise: The Values of a Boston Elite, 18001860," American Quarterly 18 (1966): 437-451.

Hartmann, Michael. "Class-specific Habitus and the Social Reproduction of the Institutional Business Elite in Germany and France." The Sociological Review 48 (2000): 241-261.

Harvey, Charles and Mairi Maclean. "Capital Theory and the Dynamics of Institutional Business Elite Networks in Britain and France." The Sociological Review 56 (2008): 103-120.

Heemskerk, Eelke and Meindert Fennema. "Network Dynamics of the Dutch Institutional Business Elite.” International Sociology 24 (2009): 807-832.

Henderson, Roger and Martyn Robertson. "Who Wants to Be an Entrepreneur? Young Adult Attitudes to Entrepreneurship as a Career." Career Development International 5 (2000): 279-287.

Higley, John, Ursula Hoffmann-Lange, Charles Kadushin, and Gwen Moore. "Elite Integration in Stable Democracies: A Reconsideration." European Sociological Review 7 (1991): 35-53.

Hjerppe, Riitta and Jukka Jalava. "Economic Growth and Structural Change. A Century and a Half of Catching-up." In The Road to Prosperity: An Economic History of Finland, edited by Jari Ojala, Jari Eloranta and Jukka Jalava, 33-64. Helsinki: SKS, 2006.

Hoekstra, Hans A. "A Career Roles Model of Career Development.” Journal of Vocational Behavior 78 (2011): 159-173.

Ibarra, Herminia and Roxana Barbulescu. "Identity as Narrative: Prevalence, Effectiveness, and Consequences of Narrative Identity Work in Macro Work Role Transitions." Academy of Management Review 35 (2010): 135-154.

Iellatchitch, Alexander, Wolfgang Mayrhofer, and Michael Meyer. "Career Fields: A Small Step towards a Grand Career Theory?" International Journal of Human Resource Management 14 (2003): 728-750.

Jensen, David A. and Enakshi Choudhuri. "Stability and Change in 25-Year Occupational Career Patterns.” The Career Development Quarterly 50 (2001): 3-19.

Jones, Andrew. "Re-theorising the Core: A 'Globalized' Institutional Business Elite in Santiago, Chile.” Political Geography 17 (1998): 295-318.

Kadushin, Charles. "Friendship among the French Financial Elite.” American Sociological Review 60 (1995): 202-221.

Kansikas, Juha. "The Business Elite in Finland: A Prosopographical Study of Family Firm Executives 1762-2010." Business History (2015), doi: 10.1080/ 00076791.2015.1015420.

Keats-Rohan, Katharine S. B. "Biography, Identity and Names: Understanding the Pursuit of the Individual in Prosopography." in Prosopography Approaches and Application: A Handbook, vol. 13, edited by Katharine S. B. Keats-Rohan, 139-181. Oxford: Oxford University Press, 2007.

Keskinen, Jarkko. Oma ja yhteinen etu. Kauppiaiden keskinäinen kilpailu ja yhteistyö Porin paikallisyhteisössä 1765-1845. Doctoral dissertation, University of Turku, 2012.

Keskinen, Jarkko and Kari Teräs. "Sosiaalinen pääoma ja luottamus - miten tehdä näkymätön voimavara näkyväksi?” In Luottamus, sosiaalinen pääoma, 
historia, edited by Jarkko Keskinen and Kari Teräs, 7-24. Jyväskylä: Gummerus Kirjapaino Oy, 2008.

Krause, Ryan and Matthew Semadeni. "Last Dance or Second Chance? Firm Performance, CEO Career Horizon, and the Separation of Board Leadership Roles." Strategic Management Journal 35 (2014): 808-825.

Krueger Jr., Norris F., Michael D. Reilly, and Alan L. Carsrud. "Competing Models of Entrepreneurial Intentions." Journal of Business Venturing 15 (2000): 411-432.

Kryshtanovskaya, Olga and Stephen White. "The Rise of the Russian Institutional Business Elite." Communist and Post-Communistic Studies 38 (2005): 293-307.

_. "From Soviet Nomenklatura to Russian Elite." Europe-Asia Studies 48 (1996): 711-733.

Lam, Simon S. K., Thomas W. H. Ng, and Daniel C. Feldman. "The Relationship between External Job Mobility and Salary Attainment across Career Stages.” Journal of Vocational Behavior 80 (2012): 129-136.

Lambkin, Brian. "Towards a Prosopography of European Migration.” AEMI Journal 8 (2010): 19-23.

Lee, Mary D., Ellen E. Kossek, Douglas T. Hall, and Jean-Baptiste Litrico. "Entangled Strands: A Process Perspective on the Evolution of Careers in the Context of Personal, Family, Work, and Community Life." Human Relations 64 (2011): 1531-1533.

Liebig, Brigitte and Silvia Sansonetti. "Career Paths." Current Sociology 52 (2004): 371-406.

Liu, Yongmei, Jun Liu, and Longzeng Wu. "Are You Willing and Able? Roles of Motivation, Power, and Politics in Career Growth." Journal of Management 36 (2010): 1432-1460.

Maclean, Mairi, Charles Harvey, and Robert Chia. "Sensemaking, Storytelling and the Legitimization of Institutional Business Elite Career." Human Relations 65 (2012): 17-40.

Maclean, Mairi, Charles Harvey, and Gerhard Kling. "Pathways to Power: Class, Hyper-agency and the French Corporate Elite.” Organization Studies 35 (2014): 825-855.

Maclean, Mairi, Charles Harvey, and Jon Press. "Managerialism and the Post-war Evolution of the French National Business System." Business History 49 (2007): 531-551.

MacLeod, Christine and Alessandro Nuvolari. "The Pitfalls of Prosopography: Inventors in the Dictionary of National Biography." Technology and Culture 47 (2006): 757-776.

Mastekaasa, Arne. "Social Origins and Recruitment to Norwegian Business and Public Sector Elites.” European Sociological Review 20 (July 2004): 221-235.

Mathisen, Ralph W. "The Prosopography of the Later Roman Empire: Yesterday, Today and Tomorrow." Proceedings of the British Academy 118 (2003): $23-40$.

McConica, James K. "The Prosopography of the Tudor University.” The Journal of Interdisciplinary History 3 (1973): 543-554. 
Mizruchi, Mark S. "What Do Interlocks Do? An Analysis, Critique, and Assessment of Research on Interlocking Directorates." Annual Review of Sociology 22 (1996): 271-298.

Moya, Maria F. "A Family-owned Publishing Multinational: The Salvat Company (1869-1988)." Business History 52 (2010): 453-470.

Muja, Naser and Steven H. Appelbaum. "Cognitive and Affective Processes Underlying Career Change." Career Development International 17 (2012): 683-701.

Napolitano, Maria Rosaria, Vittoria Marino and Jari Ojala. "In Search of an Integrated Framework of Business Longevity.” Business History (2015). doi: 10.1080/00076791.2014.993613.

Nordqvist, Mattias. "Understanding Strategy Processes in Family Firms: Exploring the Roles of Actors and Arenas." International Small Business Journal 30 (2012): 24-40.

Ojala, Jari. "Kerran porvareita. Suomalaisten kauppiassukujen sosioekonomisen aseman muutos.” In Keulakuvia ja peränpitäjiä, edited by Riitta Oittinen and Marjatta Rahikainen, 199-216. Helsinki: Suomen Historiallinen Seura, Paloheimo 2012.

Ojala, Jari and Vilma Luoma-Aho. "Sidosryhmäsuhteet liiketoiminnan sosiaalisena pääomana merkantilismista globaalitalouteen." In Luottamus, sosiaalinen pääoma, historia, edited by Jarkko Keskinen and Kari Teräs, 121-146. Jyväskylä: Gummerus Kirjapaino Oy, 2008.

Ojala, Jari and Petri Karonen. "Business: Rooted in Social Capital over the Centuries." In The Road to Prosperity: An Economic History of Finland, edited by Jari Ojala, Jari Eloranta, and Jukka Jalava, 93-126. Helsinki: SKS, 2006.

Paloheimo, Maare. Business Life in Pursuit of Economic and Political Advantages in Early-nineteenth-century Finland. Doctoral dissertation, University of Jyväskylä, Finland, 2012.

Parasuraman, Saroj, Yasmin S. Purohit, Veronica M. Godshalk, and Nicholas J. Beutell. "Work and Family Variables, Entrepreneurial Career Success, and Psychological Well-being." Journal of Vocational Behavior 48 (1996): 275-300.

Patzelt, Holger and Dean A. Shepherd. "Negative Emotions of an Entrepreneurial Career: Self-employment and Regulatory Coping Behaviors." Journal of Business Venturing 26 (2011): 226-238.

Plamper, Jan. "The Russian Orthodox Episcopate, 1721-1917: A Prosopography." Journal of Social History 34 (Autumn 2000): 5-34.

Riviezzo, Angelo, Mika Skippari, and Antonella Garofano. "Who Wants to Live Forever: Exploring 30 Years of Research on Business Longevity." Business History (2015). doi: 10.1080/00076791.2014.993617.

Ruggini, Lellia C. "Rome in Late Antiquity: Clientship, Urban Topography, and Prosopography." Classical Philology 98 (October 2003): 366-382.

Ruostetsaari, I. "Nordic Elites in Comparative Perspective." Comparative Sociology 6 (2007): 158-189.

. "Social Upheaval and Transformation of Elite Structures: The Case of Finland.” Political Studies 54, no. 1 (2006): 23-42. 
—. "The Anatomy of the Finnish Power Elite." Scandinavian Political Studies 16 (1993): 305-337.

Ruostetsaari, Ilkka and Sami Borg. "Sukupolvien valta-asemien muutos eliiteissä ja eduskunnassa." Yhteiskuntapolitiikka 69 (2004): 147-158.

San Román, Elena, Paloma Fernández Pérez, and Águeda Gil López. "As Old as History: Family-controlled Business Groups in Transport Services: The Case of SEUR.” Business History 56 (2014): 1201-1222.

Saveth, Edward N. "Education of an Elite." History of Education Quarterly 28 (1998): 367-386.

Shapin, Steven and Arnold Thackray. "Prosopography as a Research Tool in History of Science: The British Scientific Community, 1700-1900.” History of Science 12 (1974): 1-28.

Sharma, Pramodita and Carlo Salvato. "Family Firm Longevity: A Balancing Act between Continuity and Change." In The Endurance of Family Businesses: A Global Overview, edited by Paloma Fernández Pérez and Andrea Colli, 34-56. Cambridge: Cambridge University Press, 2013.

Smith, Joan M. "Reflections on Using Life History to Investigate Women Teachers' Aspirations and Career Decisions." Qualitative Research 12 (2012): 486-503.

Spitzer, Alan B. "Malicious Memories: Restoration Politics and a Prosopography of Turncoats." French Historical Studies 24 (2001): 37-61.

Stokes, Ray and Ralf Banken. "Constructing an 'Industry': The Case of Industrial Gases, 1886-2006.” Business History (2015). doi: 10.1080/00076791. 2014.975123

Sullivan, Sherry E. and Yahuda Baruch. "Advances in Career Theory and Research: A Critical Review and Agenda for Future Exploration.” Journal of Management 25 (2009): 1542-1571.

Teague, Paul and Jimmy Donaghey. "The Life and Death of Irish Social Partnership: Lessons for Social Pacts.” Business History (2015). doi: 10.1080/ 00076791.2014 .983482$.

Uotila, Merja. Käsityöläinen kyläyhteisönsä jäsenenä: prosopografinen analyysi Hollolan käsityöläisistä 1810-1840. Doctoral dissertation, University of Jyväskylä, Finland, 2014.

Useem, Michael. "The Social Organization of the American Institutional business elite and Participation of Corporation Directors in the Governance of American Institutions.” American Sociological Review 44 (1979): 553-572.

Useem, Michael and Arlene McCormack. "The Dominant Segment of the British Institutional Business Elite.” Sociology 15 (1981): 381-406.

Veiga, John F. "Mobility Influences During Managerial Career Stages." The Academy of Management Journal 26 (1983): 64-85.

Verboven, Koenraad, Myriam Carlier, and Jan Dumolyn. "A Short Manual to the Art of Prosopography." In Prosopography Approaches and Applications: A Handbook, edited by Katharine S. B. Keats-Rohan, 35-69. Oxford: Unit for Prosopographical Research (Linacre College), 2007.

van Vianen, Annelies E. M., Irene E. De Pater and Paul T. Y. Preenen. "Adaptable Careers: Maximizing Less and Exploring More." The Career Development Quarterly 57 (2009): 298-309. 
West, Allen B. "Notes on Achaean Prosopography and Chronology." Classical Philology 23 (1928): 258-269.

Yoo, Taeyoung and Soo Hee Lee. "In Search of Social Capital in State-activist Capitalism: Elite Networks in France and Korea." Organization Studies 30 (2009): 529-547.

Zellweger, Thomas and Philipp Sieger. "Entrepreneurial Orientation in LongLived Family Firms.” Small Business Economics 38 (2012): 67-84.

Zhao, Hao, Scot E. Seibert, and Gerald E. Hills. "The Mediating Role of Self-efficacy in the Development of Entrepreneurial Intentions." Journal of Applied Psychology 90 (2005): 1265-1272.

Zhou, Min and Rebecca Y. Kim. "Formation, Consolidation, and Diversification of the Ethnic Elite: The Case of the Chinese Immigrant Community in the United States." Journal of International Migration and Integration 2 (2001): 227-247.

\section{Online Sources}

http://www.kansallisbiografia.fi/talousvaikuttajat/)

Hassinen, E. "Biography of Arvi Tammivuori," downloaded from the Suomen Talouselämän Vaikuttajat-project database 2015.

—_. "Biography of Aarne Mustakallio," downloaded from the Suomen Talouselämän Vaikuttajat-project database 2015.

Hoffman, K. "Biography of Peter Malm," Suomen talouselämän vaikuttajatproject. Downloaded from the project database 2015.

—_. "Biography of Sven Fazer," downloaded from the Suomen Talouselämän Vaikuttajat-project database 2015.

Luoma-Aho, J. "Biography of David Pulkkinen," downloaded from the Suomen Talouselämän Vaikuttajat-project database 2015.

Mansner, M. "Biography of Krister Ahlström," downloaded from the Suomen Talouselämän Vaikuttajat-project database 2015.

Mäntylä, I. and A. Mäkelä-Alitalo, ”Biography of Johan Sederholm,” downloaded from the Suomen Talouselämän Vaikuttajat-project database 2015.

Määttä, V. "Biography of Aatu Kolehmainen," downloaded from the Suomen Talouselämän Vaikuttajat-project database 2015.

Valtonen, H. "Biography of Maarit Toivanen-Koivisto," downloaded from the Suomen Talouselämän Vaikuttajat-project database 2015.

Vesikansa, J. "Biography of R. Erik Serlachius," downloaded from the Suomen Talouselämän Vaikuttajat-project database 2015.

—. "Biography of Wilhelm Sohlberg," downloaded from the Suomen Talouselämän Vaikuttajat-project database 2015.

Yrjänä, J. “Biography of Jean Bruun,” downloaded from the Suomen Talouselämän Vaikuttajat-project database 2015. 